\title{
The Effectiveness of Animation Video to Improve The Student's Learning Interest in Thematic Lesson In The Third Grade of Girimulyo Elementary School In 2020/2021
}

\section{Siti Anifah}

SD Negeri Girimulyo

stevanie.aniv@gmail.com

\section{Article History}

accepted 14/11/2020

\begin{abstract}
The purpose of this study was to increase students' interest in learning in sub-theme 4, the subject of changes in the form of objects around me in class 3 at Girimulyo Elementary School in 2020/2021. This type of research is the Classroom Piercing Research (PTK) which is carried out in 2 cycles. The stages of each cycle are planning, implementing, observing and reflecting. The author makes observations and provides an evaluation test in each cycle to determine the development of students. In cycle 1, students who scored above the KKM reached $70 \%$. After the improvement was carried out in cycle 2, the scores of students who reached the KKM were 93\%. This result shows that video animation can increase students' interest in learning in Thematic learning for grade 3 SDN Girimulyo..
\end{abstract}

Keywords: Learning interests, animated videos, thematic

\section{Abstrak}

Tujuan penelitian ini adalah untuk Meningkatkan Minat Belajar Peserta Didik Pada Pembelajaran Sub Tema 4 Kejaiaban Perubahan Wujud Benda Di Sekitarku Di Kelas 3 Sdn Girimulyo Tahun 2020/2021. Jenis penelitian yang dilakukan adalah Penelitian Tindalan Kelas (PTK) yang dilaksanakan dalam 2 siklus. Tahapan setiap siklusnya adalah perencanaan, pelaksanaan, observasi dan refleksipenulis melakukan observasi serta memberikan tes evaluasi dalam setiap siklusnya untuk mengetahui perkembangan peserta didik. Pada siklus 1 peserta didik yang mendapatkan nilai di atas KKM mencapai $70 \%$. Setelah dilaksanakan perbaikan di siklus 2 nilai peserta didik yang mencapai KKM yaitu $93 \%$ hasil ini menunjukkan bahwa video animasi dapat meningkatkan minat belajar peserta didik dlam pembelajaran Tematik kelas 3 SDN Girimulyo

Kata kunci: Minat belajar, video animasi,tematik

Social, Humanities, and Education Studies (SHEs): Conference Series https://jurnal.uns.ac.id/shes

p-ISSN 2620-9284

e-ISSN 2620-9292 


\section{PENDAHULUAN}

Kurikulum 2013 (K-13) adalah kurikulum yang berlaku dalam Sistem Pendidikan Indonesia. Kurikulum ini merupakan kurikulum tetap yang diterapkan oleh pemerintah untuk menggantikan Kurikulum-2006 atau yang sering disebut sebagai Kurikulum Tingkat Satuan Pendidikan (KTSP) yang telah berlaku selama kurang lebih 6 tahun. Kurikulum 2013 masuk dalam masa percobaanya pada tahun 2013 pada beberapa sekolah. Tujuan Kurikulum 2013 yang diterapkan oleh Kemendikbud tertuang pada Permendikbud No. 69 Tahun 2013 Tentang Kerangka Dasar Dan Struktur Kurikulum Sekolah Menengah Atas/Madrasah Aliyah) yang berbunyi: "Tujuan Kurikulum 2013 adalah mempersiapkan manusia Indonesia agar memiliki kemampuan hidup sebagai pribadi dan warga Negara yang beriman, produktif, kreatif, inovatif, dan afektif serta mampu berkontribusi pada kehidupan bermasyarakat, berbangsa,bernegara, dan peradaban dunia."

Dimyati dan Mudjiono (2002:51) berpendapat bahwa proses pembelajaran akan lebih efektif apabila siswa lebih aktif berpartisipasi dalam proses pembelajaran. Melalui partisipasi seorang siswa akan dapat memahami pelajaran dari pengalamannya sehingga akan mempertinggi hasil belajarnya. Sejauh ini, pembelajaran yang berpusat pada guru masih sering dilakukan. Banyak guru yang melaksanakan kegiatan belajar mengajar sebatas pada tugas guru yaitu memberi dan tugas peserta didik adalah menerima. Guru memberikan informasi dan mengharapkan peserta didik untuk menghafal dan mengingatnya. Guru aktif memberikan pengetahuan dan peserta didik menerima pengetahuan dengan pasif.

Pengalaman di lapangan menunjukkan bahwa pembelajaran Tematik di SD Negeri Girimulyo khususnya kelas III masih dibawah target ketuntasan yang telah ditetapkan dalam KKM (Kriteria Ketuntasan Minimal) Pembelajaran Tematik kelas III SD Negeri Girimulyo. Sebagian besar siswa kurang tertarik pada Pembelajaran Tematik bahkan ada yang meremehkan karena beranggapan bahwa Tematik itu membosankan dan sulit dipahami, anggapan tersebut dikarenakan pembelajaran yang dilaksanakan oleh guru masih bersifat teaching centered, guru tidak menggunakan media pembelajaran yang bervariasi, guru tidak mengoptimalakan peran peserta didik dalam pembelajaran

Berdasarkan pengalaman tersebut peneliti menganalisis penyebabnya yaitu :

Murid tidak tertarik dengan pelajaran yang diberikan guru hal ini terlihat dengan persiapan yang dilakukan oleh peserta didik, sebagian peserta didik tidak membawa peralatan belajar yang lengkap dan sering ijin keluar saat pembelajaran berlangsung

Guru masih kurang membantu peserta didik hal ini tampak guru hanya memberikan tugas dan di tinggal keluar

Guru tidak memberikan kesempatan kepada peserta didik untuk berperan aktif dalam pembelajaran

Sebagian besar siswa kurang tertarik pada pembelajaran Tematik bahkan ada yang meremehkan terhadap Pembelajaran ini mereka beranggapan bahwa pembelajaran Tematik terlalu sulit untuk dipahami karena banyaknya mupel yang harus dikuasai sehingga peserta merasa bosan dan meremehkan nya.

Shalahuddin (1990:95) menyatakan minat sebagai perhatian yang mengandung unsur-unsur perasaan. Pernyataan Shalahudin di atas memberikan pengertian bahwa minat berkaitan dengan rasa senang atau tidak senang. Oleh karena itu, minat sangat menentukan sikap yang menyebabkan seseorang aktif dalam suatu pekerjaan atau situasi, atau dengan kata lain minat dapat menjadi sebab atau faktor motivasi dari suatu kegiatan. Menurut Moh. Uzer Usman (2001:21) Kondisi belajar mengajar yang efektif adalah adanya minat dan perhatian siswa dalam belajar. Kemudian la juga menyatakan, bahwa minat ini besar sekali pengaruhnya terhadap belajar, sebab dengan minat seseorang akan melakukan sesuatu yang diminatinya. Sebaliknya tanpa minat, seseorang tidak mungkin melakukan sesuatu. Berdasarkan pernyataan di atas, 
dapat dikatakan bahwa orang yang mempunyai minat terhadap sesuatu, ia akan berusaha lebih keras untuk memperoleh sesuatu yang diminatinya atau dengan kata lain dengan adanya minat dalam diri seseorang, maka ia akan termotivasi untuk mendapatkan sesuatu itu. Misalnya, seorang anak menaruh minat terhadap pembelajaran, maka ia akan berusaha untuk mempelajari dan mengetahui lebih banyak tentang pembelajaran

Suryosubroto (2009: 134-135) mengungkapkan, karakteristik pembelajaran tematik diantaranya, kegiatan belajar mengajar berpusat pada siswa, memberikan pengalaman langsung kepada siswa, pemisahan mata pelajaran tidak begitu jelas, menyajikan konsep dari berbagai mata pelajaran, bersifat fleksibel, dan hasil pembelajaran dapat berkembang sesuai dengan minat serta kebutuhan siswa. Dari endapat tersebut penulis melakukan penelitian dengan menggunakan video animasi dimana video Media animasi termasuk jenis media visual audio, karena terdapat gerakan video animasi dan suara. Menurut Sudrajat (2010), pembelajaran audio visual didefinisikan sebagai produksi dan pemanfaatan bahan yang berkaitan dengan pembelajaran melalui penglihatan dan pendengaran yang secara eksklusif tidak selalu harus bergantung kepada pemahaman kata-kata dan symbol-simbol sejenis.

Menurut Furoidah (2009), media animasi pembelajaran merupakan media yang berisi kumpulan video animasi yang diolah sedemikian rupa sehingga menghasilkan gerakan dan dilengkapi dengan audio sehingga berkesan hidup serta menyimpan pesan-pesan pembelajaran. Media animasi pembelajaran dapat dijadikan sebagai perangkat ajar yang siap kapan pun digunakan untuk menyampaikan materi pelajaran.

Berdasarkan teori diatas dapat disimpulkan bahwa media video animasi merupakan media pembelajaran yang berupa audio visual yang terdapat gambar yang diolah supaya gambar tersebut bergerak sehingga mampu menarik minat peserta didik dalam kegiatan pembelajaran

\section{METODE}

Penelitian ini adalah penelitian tindakan kelas (Classroom Action Research) dengan menerapkan media video animasi. mengacu pada model Kemmis \& Taggart (dalam Trianto, 2010: 30) yang terdiri dari empat komponen yaitu: (1) perencanaan (planning), (2) tindakan (acting), (3) pengamatan (observing), dan (4) refleksi (reflecting). Pada model ini, komponen tindakan dan pengamatan dilaksanakan pada waktu yang sama. Analisis penelitian ini adalah analisis deskriptif kuantitafif kualitatif dimana dalam penelitian ini selain penyajian hasil berupa data maupun angka peneliti juga menentukan bagaimana cara pengolahan hasil penelitian yakni dengan membuat analisisnya dengan menerapkan Media video animasi. Penelitian ini dilaksanakan pada peserta didik kelas III SD Negeri Girimulyo Tahun Pelajaran 2020/2021 sebanyak 2 sklus secara daring menggunakan aplikasi coom dengan satu kali pertemuan diisetiap siklusnya. Siklus I dilaksanakan pada tanggal 16 November 2020. Siklus II dilaksanakan pada tanggal 23 November 2020. Teknik pengumpulan data yang dilakukan dengan observasi dan tes. Observasi meliputi observasi keterlaksanaan media video animasi, sikap peserta didik dan keterampilan. Untuk hasil belajar menggunakan tes melalui Google form.

\section{HASIL DAN PEMBAHASAN}

Berdasarkan pelaksanaan perbaikan pembelajaran pada siklus pertama minat belajar siswa dalam proses pembelajaran sudah terlihat. Hal ini dari minat belajar siswa dalam berpartisipasi dan antusias mereka dalam mengikuti kegiatan belajar mengajar. Namun ada beberapa siswa yang pasif dan belum berani mengemukakan 
pendapat, bertanya/menjawab pertanyaan dari guru. Hasil nilai evaluasi rata-rata mencapai $70 \%$.

Pada pelaksanaan perbaikan pembelajaran siklus kedua ada peningkatan minat peserta didik dalam pembelajaran hal ini tampak pada keaktifan dan antusias mereka. Peningkatan minat belajar siswa mempengaruhi tingkat pemahaman siswa sehingga nilai evaluasi pada siklus kedua ini rata-rata mencapai $87 \%$.

Hasil analisa minat belajar dan Keaktifan Peserta Didik pada setiap siklus dapat digambarkan sebagai berikut:

Tabel 1. Hasil analisa minat belajar dan Keaktifan Peserta Didik

\begin{tabular}{ccccc}
\hline & \multicolumn{2}{c}{ Minat Belajar } & \multicolumn{2}{c}{ Keaktifan Peserta Didik } \\
\hline Ya & Siklus I & Siklus II & Siklus I & Siklus II \\
Tidak & 18 & 26 & 20 & 28 \\
$\begin{array}{c}\text { Persentase } \\
\text { aktif }\end{array}$ & 12 & 4 & 10 & 2 \\
\hline
\end{tabular}

Berasarkan tabel di atas dapat penulis gambarkan dalam bentuk diagram sebagai berikut :

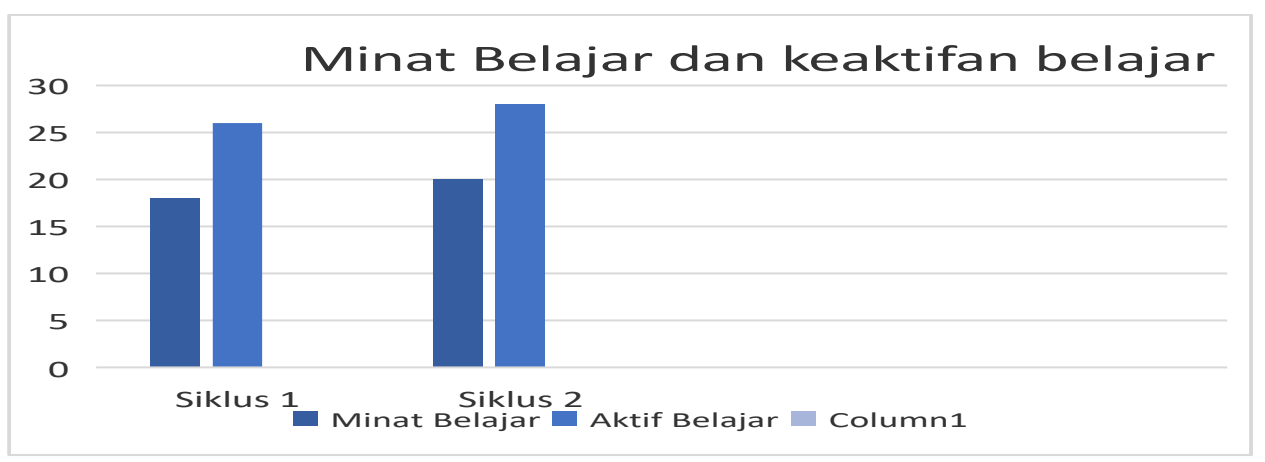

Gambar 1. Grafik Minat Belajar dan Keaktifan Belajar

Berdasarkan diagram batang diatas penulis menemukan minat belajar dan keaktifan peserta didik mengalami peningkatan yang signifikan, dari siklus 1 peserta didik minat belajar Tematik kelas 3 tema 3 ada $60 \%$ mengalami peningkatan menjadi $86 \%$ pada siklus 2, keaktifan peserta didik mengalami peningkatan dari siklus 1 ada $66 \%$ meningkat menjadi $93 \%$ hal ini menunjukkan bahwa Video Animasi meningkatkan minat belajar dan keaktifan peserta didik pada Tematik tema 4 perubahan wuujud benda disekitarku kelas 3 . berikut :

Adapun prestasi hasil belajar peneliti gambarkan dalam bentuk tabel dan grafik Tabel 2. Prestasi Hasil Belajar

\begin{tabular}{ccccccccc}
\hline & $\begin{array}{c}\text { Banyak } \\
\text { soal }\end{array}$ & $\begin{array}{c}\text { Skor } \\
\text { maks }\end{array}$ & $\begin{array}{c}\text { Jumla } \\
\text { siswa } \\
\text { siswa }\end{array}$ & Ya & Tidak & Ketuntasan & $\begin{array}{c}\text { Rata } \\
\text {-rata }\end{array}$ & $\begin{array}{c}\text { Presenta } \\
\text { se Nilai } \\
\text { Rata- } \\
\text { rata }\end{array}$ \\
\hline $\begin{array}{c}\text { Siklus } \\
\text { I }\end{array}$ & 15 & 100 & 30 & 21 & 9 & $70 \%$ & 78 & 78 \\
$\begin{array}{c}\text { Siklus } \\
\text { II }\end{array}$ & 15 & 100 & 30 & 28 & 2 & $93 \%$ & 88 & 88 \\
\hline
\end{tabular}




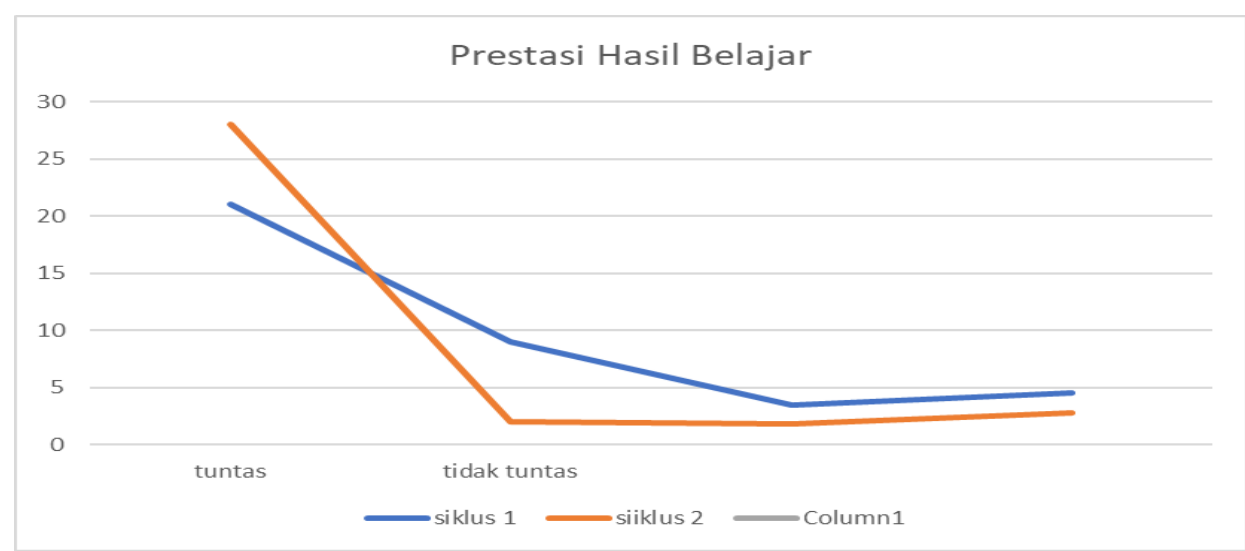

Gambar 2. Grafik prestasi belajar siswa siklus I dan siklus II

Bedasarkan grafik di atas dapat dinyatakan bahwa Prestasi belajar peserta didik kelas 3 mengalami peningkatan hal ini dapat dilihat dari perolehan nilai peserta didik dari siklus 1 peserta didik yang mencapai KKM (70) sebanyak 21 siswa dari 30 siswa, prosentase sebesar $78 \%$ sedangkan peserta didik yang belum memenuhi Kriteria Ketuntasan Minimal sebanyak 9 peserta didik atau sebesar $30 \%$, mengalami peningkatan yang cukup signifikan pada siklus 2 yaitu jumlah peserta didik yang sudah mmencapai KKM sebanayak 28 peserta didik atau $88 \%$ dan jumlah peserta didik yang belum tuntas menurun menjadi 2 peserta didik atau $6.6 \%$

Berdasarkan hasil perbaikaan di 2 siklus yang dilaksanakan selama 12 hari sebanyak 2 kali pertemuan tersebut dapat dipastikan bahwa Video Animasi dapat meningkatkan minat belajar peserta didik pada pembelajaran Tematik kelas 3 SDN Girimulyo hal ini sesuai dengan konsep atau teori yang di ungkapkan oleh Hidayat (2010) Manfaat secara umum, media dalam proses pembelajaran adalah memperlancar interaksi antara guru dengan siswa sehingga kegiatan pembelajaran akan lebih efektif dan efisien. Hal ini terbukti bahwa media video animasi mampu meningkatkan minat belajar peserta didik pada pembelajaran tematik di kelas 3 SDN Girimulyo tahun 2020

\section{SIMPULAN}

Penerapan media video animasi dapat meningkatkan minat belajar peserta didik serta hasil belajar peserta didik Kelas III pada Pembelajaran Tematik tema 3 benda disekitarku sub tema 4 keajaiban perubahan wujud benda di sekitarku. Peningkatan yang terjadi karena adanya kesan pembelajaran yang mendalam dari peserta didik tehadap materi yang diajarkan melalui setiap video yang dibuat. Peserta didik akan selalu teringat akan materi yang diajarkan dikarenakan mereka membangun pengerahuan mereka sendiri secara tidak langsung dengan memperhatikan video animasi pada setiap pembelajaran Tematik. Berdasarkan penelitian yang telah dilaksanakan salah satu media pembelajaran yang harus dikuasai guru adalah Media video animasi karena media ini sangat cocok digunakan dalam keadaan pandemi seperti ini, apalagi dalam kondisi belajar dari rumah. Peserta didik akan tertarik mengikuti pembelajaran dan antusias dalam menyelesaikan tugas mereka. Guru bias mengembangkan kemampuannya dibidang membuat animasi agar peserta didik lebih mengagumi gurunya dimana guru mampu menciptakan media pembelajaran untuk mereka agar menyenangkan guru bias bekerjasama dengan orangtua untuk memantau kegiatan pembelajaran yang dilaksanakan melalui daring disisni peneiti menggunakan aplikasi Zoom. 


\section{DAFTAR PUSTAKA}

Akhmad, Sudrajat. 2010. Profesionalisme Guru. Akhmadsudrajat.wordpress.com /2010/11/07/tentang-profesionalisme-guru/. Akses tanggal 5 november 2020, pukul 17.35

Dimyati dan Mudjiono. 2002. Belajar dan Pembelajaran. Jakarta: Rineka Cipta dan Depdikbud.

Furoidah. 2009. Pengertian Media Pembelajaran. (Online), https://kamriantiramli.wordpress.com/tag/kelebihan-dan-kekurangan-mediaanimasi/ . Diakses tgl 5 November 2020.

Kemmis, S. \& Mc. Taggart, R. 1988. The Action Research Planner. Victoria: Deakin University Press.

Permendikbud Republik Indonesia Nomor 69 (2013). Tentang Kerangka Dasar dan Struktur Kurikulum Sekolah Menengah Atas/Madrasah Aliyah.

Shalahuddin, Mahfud. 1990. Pengantar Psikologi Pendidikan. Surabaya : Bina Ilmu Uzer Usman, Moh. 2001 Menjadi Guru Profesional, Bandung : Rosda Karya

Suryosubroto. 2009. Proses Belajar Mengajar di Sekolah. Jakarta: Rhineka Cipta. Usman. User. 2008. Menjadi Guru Profesional. Bandung: PT Remaja Rosdakarya 